\title{
Impact of Environmental and Social Costs on Performance of Nigerian Manufacturing Companies
}

\author{
Agbiogwu A. A. ${ }^{1}$, Ihendinihu J. U. ${ }^{2} \&$ Okafor M. C. ${ }^{2}$ \\ ${ }^{1}$ Department of Accountancy, Alvan Ikoku Federal College of Education, Imo Sate, Nigeria \\ ${ }^{2}$ Department of Accounting, Micheal Okpara University of Agriculture, Umudike, Umuahia \\ Correspondence: Agbiogwu A. A., Department of Accountancy, Alvan Ikoku Federal College of Education, Imo \\ Sate, Nigeria. Tel: 234-803-542-3331. E-mail: andy255k@gmail.com
}

Received: April 28, 2016

doi:10.5539/ijef.v8n9p173
Accepted: August 2, 2016

URL: http://dx.doi.org/10.5539/ijef.v8n9p173

Online Published: August 25, 2016

\begin{abstract}
This study examines the impact of environmental and social costs on performance of Nigerian manufacturing companies. With the use of secondary data, sourced from ten (10) randomly selected firms' annual report and financial summary 2014. The study makes use of t- test of Spss version 20 for the analysis of collected data. Finding from the analysis shows that the sample companies environmental and social cost significantly affect Net profit margin, Earnings per share and Return on capital employed of manufacturing companies. The researchers recommended that government should ensure complete adherence of environmental laws by manufacturing companies in Nigeria.
\end{abstract}

Keywords: companies annual reports, environmental cost, social cost, manufacturing

\section{Introduction}

The state of the world's environment and the impact of mankind on the ecology of the world at large have led to the increased public concern and scrutiny of the operations and performances of companies. Companies are now expected to be able to demonstrate that they are aware and addressing the impact of their operations on the environment and society in general. The rapid growth in business activities has brought the need for companies to disclose their' environmental and social activities in the annual report and accounts under corporate social responsibility. In this regards, businesses are expected to take into cognizance a wide array of social interests and expenditure on environmental activities.

In the light of increasing deleterious effects of environmental pollution, great importance is attached not only to the financial aspects (profitability) of companies but also to its environmental and social impact. The understanding of Corporate Social Responsibility (CSR) and its wide coverage made it to emphasize on responsibility towards the company's employees, local community, society and the future generation, Malgorzata and Agnieszka (2013).

With the present regulations on environmental management in Nigeria, manufacturing companies are subjected to comply with the environmental regulation. By so doing, they incur costs, whether this cost improve or reduce financial performance is the central question that will be explored by this research

\subsection{Problem of the Study}

The increasing concern about environmental degradation and resources depletion. (especially in the Niger Delta area) is a source of worry. And also, many manufacturing companies in Nigeria are usually faced with youth restiveness as a result of unemployment, and non-availability of social amenities. This has led to series of vandalization of Oil pipelines and other valuable companies' properties. The above problem could be averted if the manufacturing companies manage their social and environmental cost efficiently and effectively. It is in the light of the above that the researcher deemed it fit to carry out an empirical study on how the manufacturing companies can manage their environmental and social cost and at the same time break-even.

\subsection{Objective of the Study}

The main objective of this paper is an assessment on the impact of environmental and social costs on the performance of manufacturing companies in Nigeria. 
Specifically, the objectives include:

To determine the significant effect of environmental and social cost on:

i. Net profit of the manufacturing company

ii. Return on capital employed (ROCE)

iii. Earnings per share (EPS)

\subsection{Hypotheses}

For the purpose of this paper, the following null hypotheses have been formulated:

1). Ho: Environmental and social cost has no significant effect on the Net profit margin(NP) of manufacturing companies.

2). Ho: Environmental and social cost does not significantly affect Return on capital Employed (ROCE) of manufacturing companies.

3). Ho: Environmental and social cost (ESC) has no significant effect on the Earnings per share (EPS) of manufacturing companies.

\section{Literature Review}

\subsection{Conceptual Framework}

Environmental and social cost accounting, social accounting otherwise known as (social accounting and auditing, social and environmental accounting, corporate social responsibility reporting, non-financial reporting or accounting) "is the process of communicating the social and environmental effects of organizations' economic actions to particular interest group within the society and to society at large" (Gray, Owen, \& Mannders, 1987). They further emphasized that the social accounting entails corporate accountability. In the words of Crowther (2000), social accounting is an "approach to reporting a firm's activities which stresses the need for the identification of socially relevant behaviour, the determination of those to whom the company is accountable for its social performance and the development of appropriate measures and reporting techniques.

On the other hand, environmental accounting according to Gray, Owen, and Adams (1996) "is a subset of social accounting, focuses on the cost structure and environmental performance of a company". It principally describes the preparation, presentation and communication of information related to an organization's interaction with the natural environment. They further stated that environmental accounting is most commonly undertaken as voluntary self -reporting by companies, third-party reports by government agencies NGOs and other bodies posit to pressure for environmental accountability.

Accounting for impacts on the environment may occur within a company's financial statements, relating to liabilities, commitments and contingencies for the remediation of contaminated lands or other financial concerns arising from pollution.

\subsubsection{Benefits of Implementing Social Accounting Practices by Companies}

Social accounting for the purpose of management control is designed to support. and facilitate the achievement of an organization's own objectives.

In the words of (Gray, 2000), organizations are seen to benefit from implementing social accounting practices in a number of ways, example:

$>$ Increased information for decision making

$>$ More accurate product or service costing

$>$ Enhanced image management and public relations

$>$ Identification of market development opportunities

$>$ Maintaining legitimacy

The society is also seen to profit from the implementation of a social and environmental accounting in many ways, thus:

$>$ Honouring stakeholders' rights of information

$>$ Balancing corporate power with corporate responsibility

$>$ Increasing transparency of corporate activity 
$>$ Identifying social and environmental costs of economic success (Gray,

$>$ Owen and Adams, 1996).

In contributing to their quota Adediran, and Alade (2013) pointed out a few benefits of environmental costs accounting to entities as follows:

$>$ It can be significantly reduced or eliminated as a result of a business decision

$>$ Environmental cost can be offset by generating revenues through sale of waste, by-products or transferable pollution allowances or licensing of clean technologies.

$>$ Better management of environmental costs can result in improved environmental performance and significant benefits to human health as well as business success.

$>$ Understanding the environmental costs and performance of processes and products can promote more accurate costing and pricing of products and can aid companies in the design of more environmentally preferable processes, products and services for the future.

From the foregoing, analyzing it implies that the environmental and social cost accounting ensures accountability and transparency of companies activities which affect different stakeholders.

\subsection{Theoretical Framework}

There are different theoretical frameworks used as a motivation to explain' reasons why many corporate bodies all over the world may provide voluntary disclosure of their corporate social responsibilities. This paper adopted, the stakeholders' theory.

\subsubsection{Instrumental Stakeholders Theory}

This theory is formed from two theories and suggests that there is positive relationship between Corporate Social Performance (CSP) and Corporate Financial performance (CFP). In the first place, instrumental theory is an economic theory that predicts what results will occur as a result of management decisions (Jones, 1995). The second theory is an ethical theory that proposes managers have a duty to put stakeholders' needs first than to increase the value of the firm. This theory is broader than the shareholders theory, which argues managers, only have a duty to maximize the value of shareholders (Dibia, 2015), Watts and Zimmerman (1978) and Chain (1996). The instrumental stakeholders' theory suggests Corporate Social Responsibility increases stakeholders satisfaction and lastly financial performance. The proponents of this theory were of the view that the increase in expenditure in corporate social responsibility (CRS) projects in the decade suggest managers find an economic benefit from CSR programme. They further stated that most of the studies find a positive relationship (Van Beurden and Gossling (2008), Wu (2006), Allouch and Laroche, (2005), Orlitzky, Schmidt, and Rynes (2003).

\subsection{Empirical Review}

Related topics have been researched in this area, but notable amongst them is (Uwaigbe, 2012) on corporate environmental disclosures in Nigerian manufacturing industry. The paper adopted the use of content analysis of manufacturing industry concerning the extent of disclosure. However, the paper discovered among other things that the level of environmental disclosure practices in Nigeria is still low. It concentrated much on cement manufacturing firms and fails to analyze the costs components of the firms. Also, in Adediran and Alade (2013) who researched on the impact of environmental and social Accounting on corporate performance in Nigeria used fourteen(14) randomly selected quoted companies in Nigeria. Data were collected from annual report analyzed using Regression Analysis. They discovered that there is negative relationship between Environmental Accounting and Return on Capital Employed and Earning per Share and a significant relationship between Environmental Accounting and Net Profit Margin cum Dividend per Share. Daniel (2013) is not left out, who carried out similar study on effect of Environmental regulations on financial performance of manufacturing companies in Tanzania. The study used regression analysis with a sample of five (5) selected listed manufacturing companies. The findings indicated that Environmental compliance has no significant effect on the financial performance of listed financial companies in Tanzania. Odatayo, Adeyemi, and Sajuyigbe (2014) carried out similar study on impact of corporate social responsibility on profitability of Nigerian banks. The study is an empirical investigation which sampled six(6) banks in Nigeria from 2003-2012 using annual report and with the use of simple regression analysis reviewed that there is a significant relationship between expenditure on social responsibility and profitability of banks in Ngeria. Also, Palmer (2012) carried out a study on corporate social responsibility and financial performance in USA. The study which covers 333 firms out of 500 for years 2001-2005 reviewed that corporate social responsibility and corporate financial performance have a significantly positive relationship in both directions and that corporate social performance leads to increase in 
gross margin. From the above reviews, relationship between Environmental and Social costs and firm's performance has not been clearly substantiated because; study shows both positive and negative relationships. It is therefore, the purpose of this Paper to rest the case by establishing whether there is significant effect and the extent of relationship.

\section{Methodology}

The research is a content method or non-experimental design (ideographic methodology).

In the words of Avwokeni (2006) archival record involves the search of existing records for data of the research and content analysis is a method that involves content analyzing the records (Annual reports and Accounts of manufacturing companies 2014). The population consists of fifteen (15) manufacturing companies from Food and Beverage sector, quoted in the Nigerian Stock Exchange. The sample size was taken to be ten (10), this is because they are the companies that disclosed their Annual report, of which five(5) where taken as the control which has no Environmental and social cost and five(5) as treated, that is those that have Environmental and social cost.

The companies are shown below:

Table 1. List of sampled companies in the Nigerian manufacturing industry

\begin{tabular}{lll}
\hline S/N & \multicolumn{1}{c}{$\begin{array}{c}\text { With Environmental and Social Cost (ESC) } \\
\text { (disclosed) }\end{array}$} & $\begin{array}{c}\text { Without Environmental and Social Cost (ESC) } \\
\text { (not disclosed) }\end{array}$ \\
\cline { 2 - 3 } 1 & Floor Mill Plc & UAC Foods \\
2 & Unilever Nigeria Plc & Honey Well Plc \\
3 & Cadbury Nigeria Plc & National Salt Nigeria Plc \\
4 & Dangote Sugar Plc & Presco Nigeria Plc \\
5 & Nestle Plc & Union Dicon Salt Plc. \\
& $\mathbf{N}=\mathbf{5}$ & $\mathbf{N = 5}$ \\
\hline
\end{tabular}

\subsection{Research Instrument}

The study made use of secondary data (information from the Annual reports and Accounts of manufacturing companies quoted in the Nigerian stock Exchange). The statistical tool for testing the Hypothesis was T-test using SPSS (Statistical Package for Social Sciences) version 20.

Where: Environmental and social cost $=\mathrm{ESC}$

Net Profit Margin = NPM

Earnings per share $=$ EPS

Return on capital employed $=$ ROCE

$\mathrm{ESC}=$ Summary of cost incurred by each entity on environmental and costs during the year 2014

Net Profit $=$ Net Profit during the year under review

Unit of $\mathrm{NP}=\%$

$$
\text { Net Profit }=\frac{\text { Profit after tax }}{\text { Revenue or Turnover }} \times \frac{100}{1}
$$

$$
D P S=\frac{\text { Gross dividend }- \text { Pref dividend }}{\text { No.of Ord. Share in issue and ranking for dividend }} \times \frac{100}{1}
$$

Unit of DPS $=$ Kobo

Unit of ROCE $=\%$

$$
\text { ROCE }=\frac{\text { Profit after tax }}{\text { Capital Employed }} \times \frac{100}{1}
$$

Where Capital employed $=$ Total Assets - Current Liabilities.

$$
E P S=\frac{\text { Profit after tax \& before extraordinary item less pref. Div }}{\text { No. of ordinary shares ranking for dividend }} \times \frac{100}{1}
$$

T-Test formula 


$$
t=\frac{\overline{x_{1}}-\overline{x_{2}}}{\sqrt{\frac{s_{1}^{2}}{n_{1}}+\frac{s_{2}^{2}}{n_{2}}}}
$$

Where

$\overline{x_{1}}=$ Mean of first set of values

$\overline{x_{2}}=$ Mean of second set of values

$\mathrm{S}_{1}=$ Standard deviation of first set of values

$S_{2}=$ Standard deviation of second set of values

$\mathrm{n}_{1}=$ Total number of values in first set

$\mathrm{n}_{2}=$ Total number of values in second set.

$$
s=\sqrt{\frac{\sum(x-\bar{x})^{2}}{n-1}}
$$

$\mathrm{x}=$ Values given

$\bar{x}=$ mean

$\mathrm{n}=$ Total number of values.

\section{Data Analysis, Results, Findings, Conclusion \& Recommendations}

\subsection{Testing of Hypotheses}

\subsubsection{Hypothesis One}

Ho: Environmental and Social Cost does not significantly affect Net Profit Margin of Manufacturing Companies.

Ha: Environmental and Social Cost significantly affects Net Profit Margin of Manufacturing Companies.

Table 2. Group statistics for net profit margin

\begin{tabular}{lllccc}
\hline \multirow{2}{*}{ NPM } & Group & N & Mean & Std. Deviation & Std. Error Mean \\
\cline { 2 - 6 } & With ESC & 5 & 2.2482 & .13331 & .05962 \\
& Without ESC & 5 & 1.0068 & .43993 & .19674 \\
\hline
\end{tabular}

Note. ESC=Environmental Social Cost; NPM=Net Profit Margin.

\begin{tabular}{|c|c|c|c|c|c|c|c|c|c|c|}
\hline & & \multicolumn{2}{|c|}{$\begin{array}{c}\text { Levene's Test for } \\
\text { Equality of Variances }\end{array}$} & \multicolumn{7}{|c|}{ t-test for Equality of Means } \\
\hline & & \multirow[t]{2}{*}{$\mathrm{F}$} & \multirow[t]{2}{*}{ Sig. } & \multirow[t]{2}{*}{$\mathrm{T}$} & \multirow[t]{2}{*}{ Df } & \multirow[t]{2}{*}{$\begin{array}{c}\text { Sig. } \\
\text { (2-tailed) }\end{array}$} & \multirow[t]{2}{*}{$\begin{array}{c}\text { Mean } \\
\text { Difference }\end{array}$} & \multirow[t]{2}{*}{$\begin{array}{l}\text { Std. Error } \\
\text { Difference }\end{array}$} & \multicolumn{2}{|c|}{$\begin{array}{l}95 \% \text { Confidence Interval } \\
\text { of the Difference }\end{array}$} \\
\hline & & & & & & & & & Lower & Upper \\
\hline \multirow[t]{2}{*}{ NPM } & Equal variances assumed & 4.248 & .073 & 6.039 & 8 & .000 & 1.24140 & .20558 & .76733 & 1.71546 \\
\hline & Equal variances not assumed & & & 6.039 & 4.728 & .002 & 1.24140 & .20558 & .70368 & 1.77911 \\
\hline
\end{tabular}

Table 3. Independent samples test for net profit margin

Note. NPM=Net Profit Margin.

The "With ESC" group (N=5) was associated with the NPM ( $\mathrm{SD}=0.13331)$. By comparison the "Without ESC" group $(\mathrm{N}=5)$ was associated with NPM ( $\mathrm{SD}=0.43993)$. To test the hypothesis an independent samples t-test was performed as can be seen in Table 3. The assumption of homogeinity of variances was tested and satisfied using Levene's test for equality of variances, $F(8)=4.248 \mathrm{p}=0.073$, for which unequal variances was assumed since p-value(sig) $>0.05$. The mean difference was found to be 1.2414 of which chance of finding this or a larger absolute difference between the two mean is $0.2 \%$. Also the independent samples test was associated with a statistically significant effect $\mathrm{t}(8)=6.039, \mathrm{p}=0.02$, so we reject the null hypothesis that Environmental and Social Cost does not significantly affect Net Profit Margin of Manufacturing Companies and accept the alternate hypothesis. 


\subsubsection{Hypothesis Two}

Ho: Environmental and Social Cost does not significantly affect Return on Capital Employed of Manufacturing Companies.

Ha: Environmental and Social Cost significantly affects Return on Capital Employed of Manufacturing Companies.

Table 4. Group statistics for return on capital employed

\begin{tabular}{lllccc}
\hline & Group & N & Mean & Std. Deviation & Std. Error Mean \\
\hline \multirow{2}{*}{ ROCE } & With ESC & 5 & 2.2366 & .14303 & .06396 \\
& Without ESC & 5 & 1.0311 & .29856 & .13352 \\
\hline
\end{tabular}

Note. ESC=Environmental Social Cost; ROCE=Return on Capital Employed.

Table 5. Independent samples test for return on capital employed

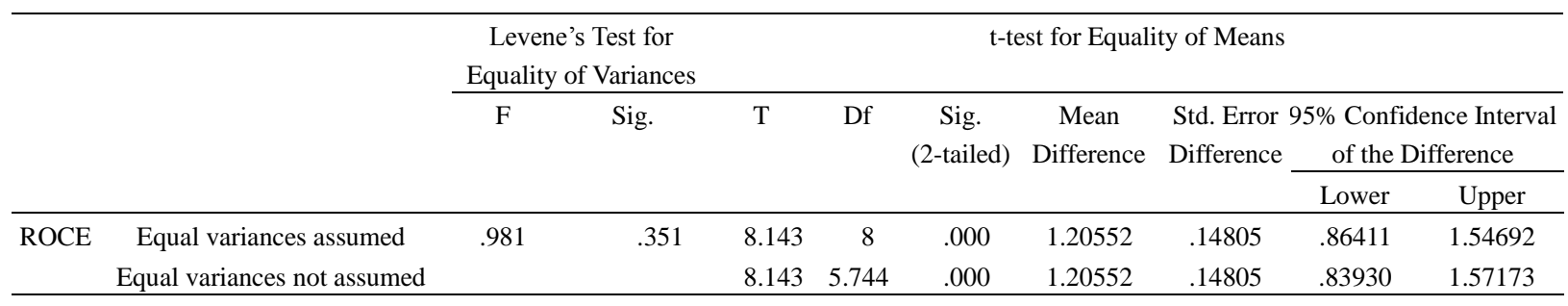

Note. ROCE=Return on Capital Employed..

The "With ESC" group (N=5) was associated with the ROCE ( $\mathrm{SD}=0.14303)$. By comparison the "Without ESC" group ( $\mathrm{N}=5$ ) was associated with ROCE ( $\mathrm{SD}=0.29856$ ). To test the hypothesis an independent samples t-test was performed as can be seen in Table 5. The assumption of homogeneity of variances was tested and satisfied using Levene's test for equality of variances, $F(8)=0.981 \mathrm{p}=0.351$, for which unequal variances was assumed since $\mathrm{p}$-value(sig) $>0.05$. The mean difference was found to be 1.20552 of which chance of finding this or a larger absolute difference between the two mean is $0.00 \%$. Also the independent samples test was associated with a statistically significant effect $t(8)=8.143, p=0.00$, so we reject the null hypothesis that Environmental and Social Cost does not significantly affect Return on Capital Employed of Manufacturing Companies and accept the alternate hypothesis.

\section{Hypothesis Three}

Ho: Environmental and Social Cost does not significantly affect Earnings per Share of Manufacturing Company.

Ha: Environmental and Social Cost significantly affect Earnings per Share of Manufacturing Companies.

Table 6. Group statistics for earnings per share

\begin{tabular}{lllccc}
\hline & Group & $\mathrm{N}$ & Mean & Std. Deviation & Std. Error Mean \\
\hline \multirow{2}{*}{ EPS } & With ESC & 5 & 2.8439 & .21879 & .09785 \\
& Without ESC & 5 & 1.4106 & .79171 & .35406 \\
\hline
\end{tabular}

Note. ESC=Environmental Social Cost; EPS=Earnings Per Share.

Table 7. Independent samples test for earnings per share

\begin{tabular}{|c|c|c|c|c|c|c|c|c|c|c|}
\hline \multicolumn{11}{|c|}{ Independent Samples Test } \\
\hline & & \multirow{2}{*}{\multicolumn{2}{|c|}{$\begin{array}{l}\text { Levene's Test for } \\
\text { Equality of Variances }\end{array}$}} & \multirow{2}{*}{\multicolumn{7}{|c|}{ t-test for Equality of Means }} \\
\hline & & & & & & & & & & \\
\hline & & \multirow[t]{2}{*}{$\mathrm{F}$} & \multirow[t]{2}{*}{ Sig. } & \multirow[t]{2}{*}{$\mathrm{T}$} & \multirow[t]{2}{*}{ df } & \multirow[t]{2}{*}{$\begin{array}{c}\text { Sig. } \\
\text { (2-tailed) }\end{array}$} & \multirow[t]{2}{*}{$\begin{array}{c}\text { Mean } \\
\text { Difference }\end{array}$} & \multirow[t]{2}{*}{$\begin{array}{l}\text { Std. Error } \\
\text { Difference }\end{array}$} & \multicolumn{2}{|c|}{$\begin{array}{c}95 \% \text { Confidence Interva } \\
\text { of the Difference }\end{array}$} \\
\hline & & & & & & & & & Lower & Upper \\
\hline \multirow[t]{2}{*}{ EPS } & Equal variances assumed & 11.710 & .009 & 3.902 & 8 & .005 & 1.43332 & .36734 & .58625 & 2.28040 \\
\hline & Equal variances not assumed & & & 3.902 & 4.607 & .013 & 1.43332 & .36734 & .46434 & 2.40231 \\
\hline
\end{tabular}

Note. Eps=Earnings Per Share. 
The "With ESC" group (N=5) was associated with the EPS ( $\mathrm{SD}=0.21879)$. By comparison the "Without ESC" group $(\mathrm{N}=5)$ was associated with EPS $(\mathrm{SD}=0.79171)$. To test the hypothesis an independent samples t-test was performed as can be seen in Table 7. The assumption of homogeneity of variances was tested and satisfied using Levene's test for equality of variances, $F(8)=11.710 \mathrm{p}=0.009$, for which equal variances was assumed since $\mathrm{p}$-value(sig) $<0.05$. The mean difference was found to be 1.433 of which chance of finding this or a larger absolute difference between the two mean is $0.9 \%$. Also the independent samples test was associated with a statistically significant effect $t(8)=3.902, p=0.005$, so we reject the null hypothesis that Environmental and Social Cost does not significantly affect Earnings Per Share of Manufacturing Companies and accept the alternate hypothesis.

\section{Discussion of Findings}

The study revealed the following findings:

Environmental and Social Cost significantly affect Net Profit Margin of Manufacturing Companies. This agrees with Palmer (2012), and also Table 3.

Environmental and Social Cost significantly affects Return on Capital Employed of Manufacturing Companies. This also agrees with Odetayo, Adeyemi, and Sajuyigbe (2014) and confirmed by Table 5.

Environmental and Social Cost significantly affect Earnings per Share of Manufacturing Companies. This agrees with Odetayo, Adeyemi, and Sajuyigbe (2014) and Palmer (2012) and confirmed with Table 7.

\section{Conclusion}

Social accounting is a wide spread practice in a number of large organizations in the United kingdom, royal Dutch shell, BR, British Telecom etc, Traidcraft plc, the fair trade organization claims to be the first public limited company to publish audited social accounts in the U.K since 1993 (Dey, 2007).

In Nigeria most of the company's especially quoted companies disclose environmental and social cost incurred during the year in their annual report and Accounts. It is time the government ensure complete adherence by companies to disclosure their environmental and social costs elements in their reports this will ensure effective environmental management system (EMS) necessary for companies engaged in international trade.

\section{Recommendations}

In view of the findings above, the following recommendations are made:

The Nigerian government should as a matter of importance make companies disclose in their annual reports and account environmental and social costs incurred.

Government should encourage companies by given tax incentive for those who comply with the environmental regulations and laws of our country

Directors/CEOs of companies should ensure that their entities comply with the environmental laws of our country.

Finally, merit awards should be given to Directors and companies who comply with the environmental laws. This will go a long way in enhancing their performances and ensure sustainability, growth of their entities.

\section{References}

Adediran, S. A., \& Alade, S. O. (2013). Impact of Environmental Accounting on Corporate Performance in Nigeria. European Journal of Business \& Management, 5(23). London.

Avwokeni, A. J. (2006). How to write and defend a research project including journal articles. Port Harcourt, Unicampus Tutorial Service.

Daniel, L. N. (2013). The effect of environmental regulation on financial performance in Tanzania: A survey of manufacturing companies quoted on the Dar Es Salam stock exchange. International Journal of Economics and Financial Issues, 3(1), 99-112.

Dey, C. (2007). Social Accounting at Traidcraft Plc: A Struggle for the meaning of fair trade. Accounting Auditing \& Accountability Journal, 20(3), 423-445. http://dx.doi.org/10.1108/09513570710748571

Gray, R. H. (2000). Current Developments and Trends in Social and Environmental Auditing, Reporting and Attestation. International Journal of Auditing, 4(3), 247-268. http://dx.doi.org/10.1111/1099-1123.00316

Gray, R. H., Owen, D. L., \& Adams, C. (1996). Accounting and Accountability: Changes and Challenges in Corporate Social and Environmental Reporting. London: Prentice Hall. 
Gray, R. H., Owen, D. L., \& Maunders, K. T. (1987). Corporate Social Reporting; Accounting and Accountability. (Hemel Hempstead), Prentice Hall.

Growther, D. (2000). Social and Environmental Accounting (p. 20). London, Finance Times Prentice Hall.

Malgorzata, K., \& Agnieszika, N. (2013). Environmental Accounting as an Expression of Implementation of Corporate Social Responsibility Concept. knowledge Management \& Innovation, 19-21.

Nigerian Stock Exchange. (2014). Annual Financial Report of Quoted Manufacturing Companies. Retrieved from http://www. topforeignstocks.com/stock-lists/the-list-of-listed-companies-in-nigeria.html

Odetayo, T. A., Adeyemi, A. Z., \& Sajuyigbe, A. S. (2014). Impact of Corporate social responsibility on profitability of Nigerian banks. International Journal of Academic Research in Business and Social Sciences, 4(8), 252-263. http://dx.doi.org/10.600//ijarbss/v4-18/1094

Palmer, H. J. (2012). Corporate social responsibility and financial performance: Does it pay to be good? CMC Senior Thesis, USA Claremont college.

Uwaigbe, U., \& Jimoh, L. (2012). Corporate Environmental Disclosure in Nigerian Manufacturing Industry. Multidisciplinary Journal Ethiopia, 6(3), 73.

Watts, R. L., \& Zimmerman, J. L. (1978). Towards a Positive Theory of the determination of Accounting Standards. Accounting Review, 54(2), 112-134.

Wiseman, J. (1982). An Evaluation of Environmental Disclosures Made in Corporate Annual Reports. Accounting Organization \& Society, 7(1), 53-63. http://dx.doi.org/10.1016/0361-3682(82)90025-3

\section{Appendix}

Table 8. Variables from companies financial statements

\begin{tabular}{|c|c|c|c|c|c|c|c|}
\hline NAME OF COMPANY & $\operatorname{ESC}(\mathbf{N})$ & ROCE (\%) & NPM $(\%)$ & EPS (Kobo) & $\log (\mathrm{NPM})$ & $\log ($ EPS $)$ & $\log ($ ROCE $)$ \\
\hline Floor Mill Plc & $41,500,000$ & 27 & 35 & 103 & 2.41 & 2.97 & 2.26 \\
\hline Unilever Nigeria Plc & $32,865,000$ & 24 & 32 & 89 & 2.36 & 2.90 & 2.18 \\
\hline Cadbury Nigeria Plc & $8,150,008$ & 10 & 22 & 85 & 2.11 & 2.88 & 2.28 \\
\hline Dangote Sugar Plc & $5,975,000$ & 28 & 33 & 99 & 2.15 & 3.00 & 2.43 \\
\hline Nestle Plc & $10,547,432$ & 36 & 25 & 38 & 2.20 & 2.46 & 2.22 \\
\hline UAC Foods & - & 12.4 & 12.7 & 225 & 1.14 & 2.35 & 1.13 \\
\hline Honey Well Plc & - & 9.4 & 6.1 & 42.26 & 0.86 & 1.64 & 1.02 \\
\hline National Salt Nigeria Plc & - & 26 & 16.6 & 0.7 & 1.25 & 1.88 & 1.43 \\
\hline Presco Nigeria Plc & - & 8.5 & 28.5 & 2.68 & 1.47 & 0.57 & 0.98 \\
\hline Union Dicon Salt Plc. & - & 3.0 & 1.12 & 3.13 & 0.33 & 0.62 & 0.60 \\
\hline
\end{tabular}

Source: 2014 Nigerian Stock Exchange Annual Financial Report.

\section{Copyrights}

Copyright for this article is retained by the author(s), with first publication rights granted to the journal.

This is an open-access article distributed under the terms and conditions of the Creative Commons Attribution license (http://creativecommons.org/licenses/by/4.0/). 